\title{
HETEROCLADIUM DIMORPHUM (HETEROCLADIACEAE, BRYOPHYTA) - AN OLD ELEMENT OF THE HUNGARIAN BRYOPHYTE FLORA REDISCOVERED
}

\author{
Kornél BARÁTH ${ }^{1 *}$, Péter ErzbergeR ${ }^{2}$, Andor KovÁcs ${ }^{3}$ and Beáta PAPP ${ }^{4}$ \\ ${ }^{1}$ Institute of Biology, University of West Hungary, \\ H-9700 Szombathely, Károlyi Gáspár tér 4, Hungary; *barath.kornel@ttk.nyme.hu \\ ${ }^{2}$ Belziger Str. 37, D-10823 Berlin, Germany \\ ${ }^{3}$ Szent István University, H-1118 Budapest, Villányi út 29-43, Hungary \\ ${ }^{4}$ Department of Botany, Hungarian Natural History Museum, H-1431 Budapest, Pf. 137, Hungary
}

Baráth, K., Erzberger, P., Kovács, A. \& Papp, B. (2016): Heterocladium dimorphum (Heterocladiaceae, Bryophyta) - an old element of the Hungarian bryophyte flora rediscovered. - Studia bot. bung. 47(2): 269-278.

\begin{abstract}
Heterocladium dimorphum is considered to be a data-deficient moss species that has been neither collected nor observed in the last 46 years in Hungary. During the systematic field studies aimed at exploring the recent bryophyte flora of the Köszeg Mts and in the framework of grid-cell based bryophyte recording, $H$. dimorphum was discovered in two new locations of the Köszeg Mts and re-found in one of the old locations in the Visegrád Mts. The size of populations is estimated and the habitats are characterized. Illustrations and a short description of the species are provided. The previous occurrences of $H$. dimorphum in Hungary are listed based on the specimens of the bryophyte collection of the Hungarian Natural History Museum, Budapest (BP). Based on the extant populations, the species is considered as endangered (EN).
\end{abstract}

Key words: data-deficient, Heterocladium, illustrations, Kőszeg Mts, red-listed bryophyte, Visegrád Mts

\section{INTRODUCTION}

The genus Heterocladium Schimp. comprises only eight species distributed in Europe, Asia, Macaronesia, North and South America (Sмiтн 2004). In Europe, four species occur: $H$. dimorphum (Brid.) Schimp., $H$. heteropterum (Brid.) Schimp., H. flaccidum (Schimp.) A. J. E. Smith, and H. wulfsbergii I. Hagen. The latter two can be found nearly exclusively in Northern and Western Europe (HodgetTs 2015). The phylogenetic position of this small genus has been uncertain for a long time. Initially, SCHIMPER (1852) placed it within Hypnaceae. Later, FLEISCHER (1922) transferred the genus to the family Thuidiaceae. This placement was accepted by the Hungarian bryologists Boros (1953, 1968) and Orbán and Vajda (1983). Brotherus (1924) divided the Thuidiaceae into four subfamilies and put the genus Heteropterum into the sub- 
family Heterocladioideae. This division was followed by HEDENÄS (1995). Later, BUCK and CRUM (1990) revising the subfamily Heterocladioideae noted that the gametophytes of the species of Heterocladium show a remarkable resemblance to the genera Pterigynandrum Hedw., Habrodon Schimp., Iwatsukiella Buck et Crum, and Myurella Schimp. These five genera share similar areolation, costal development, sexuality and distribution, and also most of them have reduced peristomes. Therefore, BUCK and CRUM (1990) put these five genera into the family Pterigynandraceae. Although this classification was accepted later by BUCK and GofFinet (2000) and GofFINET and BUCK (2004), the analysis of nucleotide sequence data suggested that Pterigynandraceae sensu BUCK and Crum (1990) is not monophyletic (Budyakova et al. 2003). According to Newton and TANGNEY (2007) the correct phylogenetic position of the genus Heterocladium is certainly out of Pterigynandraceae. In the most recent taxonomic studies the genus was placed into the monotypic family Heterocladiaceae (IGNATOV and Ignatova 2004, Ignatov et al. 2006). This was followed by Frey and STeCH (2009) and Sim-Sim et al. (2010).

One of the first described species of the genus is Heterocladium dimorphum that was published together with the descriptions of $H$. heteropterum and H. kurzii Schimp. (SCHIMPer 1852). H. dimorphum is a boreal-montane moss species occurring in Europe, Western Asia, and North America (SMITH 2004). In Europe, it is quite rare or absent in the western countries, while it is more widespread in the central and eastern regions. H. dimorphum is found in all countries surrounding Hungary (HoDGETTS 2015).

The first report of Heterocladium dimorphum from Hungary appears to be LATZEL (1930), who found the species (as H. squarrosulum (Voit) Lindb.) in the Köszeg Mts ("Walkgraben"). Although Boros (1927) also reported the species from this cross-border region, he gave localities outside present-day Hungary. The oldest collections of the species in the bryophyte collection of the Hungarian Natural History Museum (BP) date from 1947 (near Tahi in the Visegrád Mts) (Table 1). These data obviously formed the basis of the area description in Boros (1953): “K. Pilis (Tahitótfalu felett). Dt. Köszegi-hg." The later bryofloras (Boros 1968, ORBÁN and VAJDA 1983) listed the additional regions Sopron Mts, Bakony Mts, and Vendvidék.

Heterocladium dimorphum has been neither collected nor observed in the last 46 years in Hungary. For that reason, it was categorised as data-deficient taxon without any recent data in the updated checklist and red list of the Hungarian bryophytes (PAPP et al. 2010). In spite of the fact that H. dimorphum was systematically searched in some of the above mentioned regions by the authors and others (Németh, ex verb.) in the last years, it had not been found until very recently. 


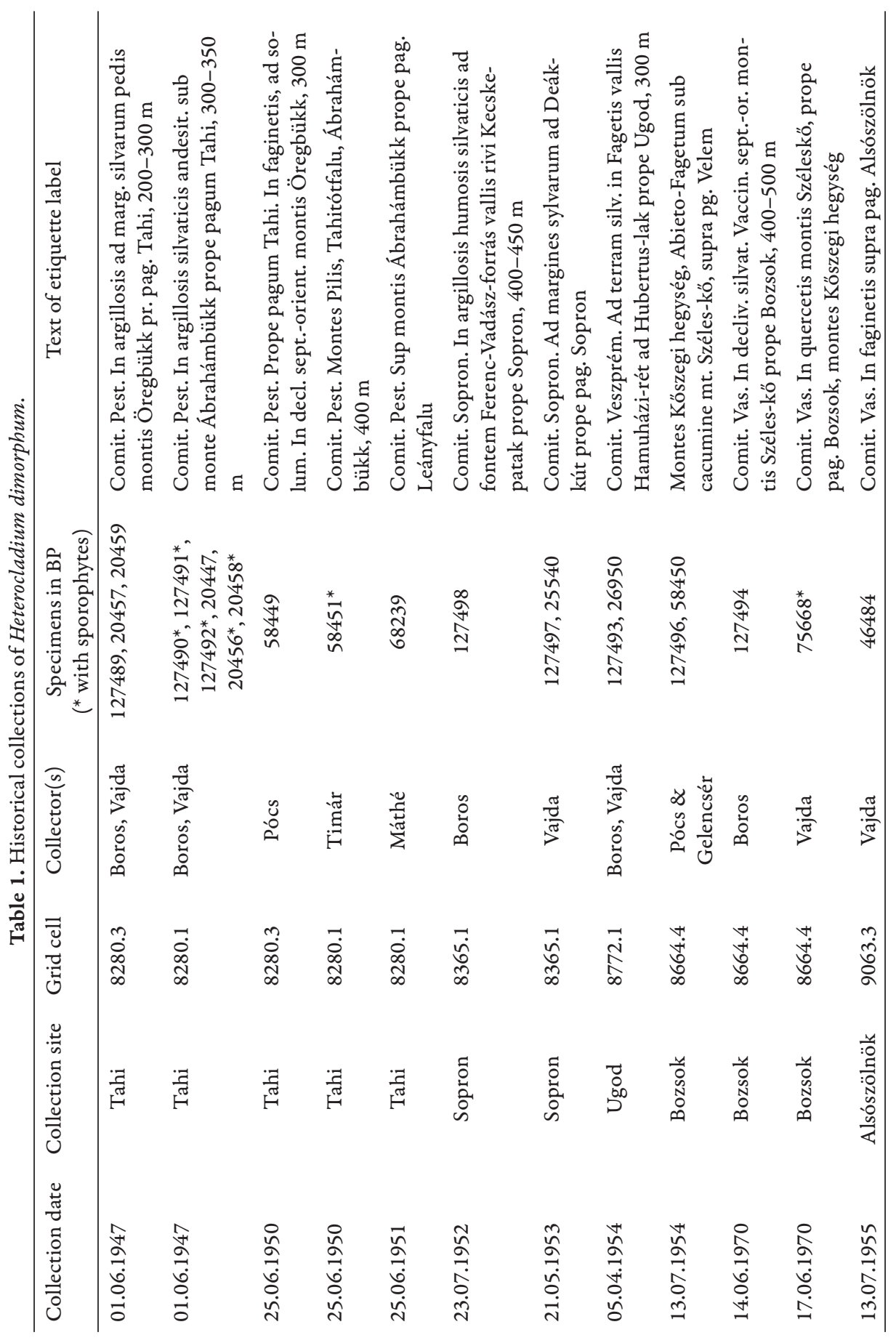




\section{MATERIAL AND METHODS}

Geographical coordinates were determined using a Garmin eTrex-30 GPS. The drawings of details of Heterocladium dimorphum were made by the first author from the following specimens: B-Erzberger 21201, 21206. The identification key for the species of the genus Heterocladium and the morphological description of $H$. dimorphum are based on Orbán and VAJDA (1983), SMITH (2004), CASAS et al. (2006), and MAGILL (2014). The nomenclature of the bryophyte taxa follows Schimper (1852), Hill (2006), Papp et al. (2010), and Ignatov and Ignatova (2004). In the case of the vascular plants the nomenclature follows KIRÁLY (2009).

\section{RESULTS AND DISCUSSION}

During the exploration of the recent bryophyte flora of the Köszeg Mts and grid-cell based bryophyte recording (ERzberger 2012, Erzberger and NÉmeth 2013), Heterocladium dimorphum was discovered in two locations of the Köszeg Mts and confirmed in the location of one of the oldest records known from Hungary in the Visegrád Mts (Fig. 1). In 2015 and 2016, Baráth and Erzberger unsuccessfully searched the species at "Szélesko", one of the his-

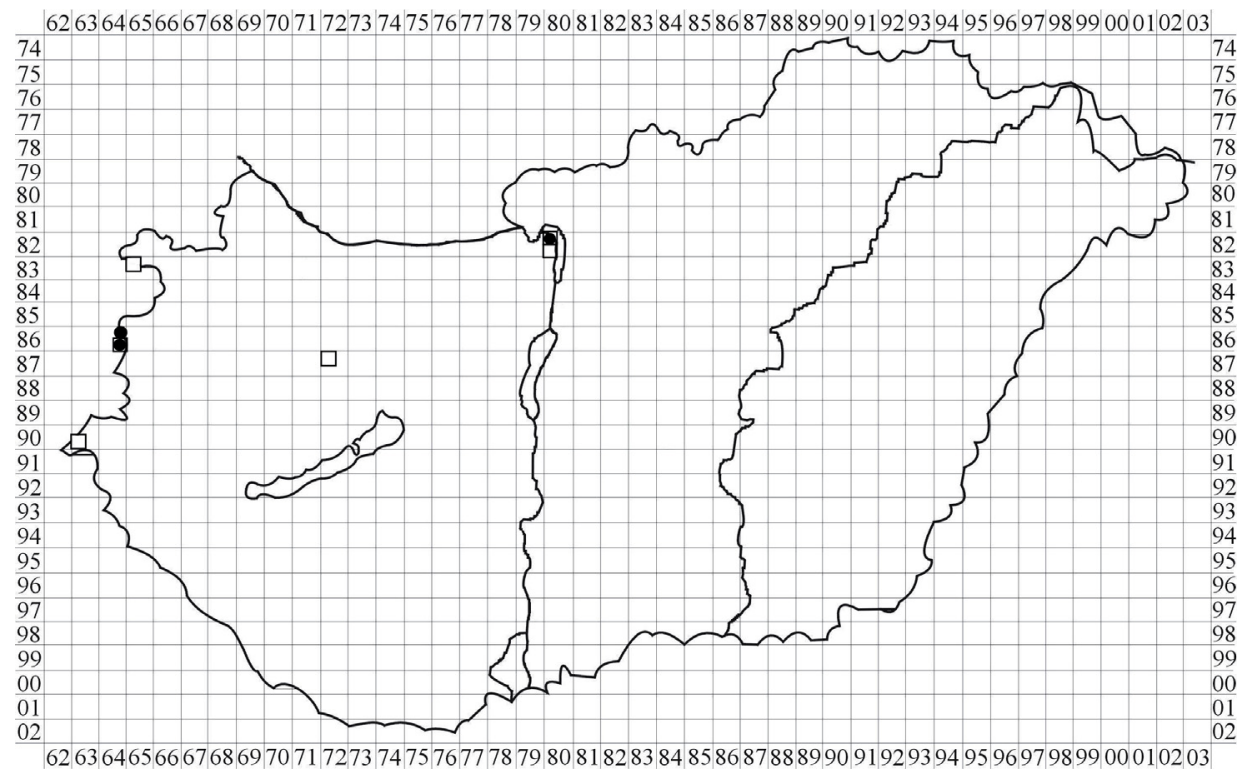

Fig. 1. Geographical locations of Heterocladium dimorphum in Hungary according to the grid of the Central European Mapping System (NI KLFELD 1971): squares = collections before 1970; dots $=$ collections in 2016 . 
torical collection sites of $H$. dimorphum in the Köszeg Mts. In addition in 2015 Erzberger searched the area near Tahi without finding the species.

However, on 2nd April 2016 a remarkably extensive population of Heterocladium dimorphum was found in an acidophilous, mixed forest (Pino-Quercetalia) between Bozsok and Velem (B-Erzberger 21201, 21206, herbarium Cs. Németh s.n., herbarium K. Baráth s.n.). In total 11 colonies of $H$. dimorphum covering an overall area of ca $3400 \mathrm{~cm}^{2}$ were observed on loamy and gritty soil. The centre of population was at $470 \mathrm{~m}, 47.339055^{\circ} \mathrm{N}, 16.477472^{\circ} \mathrm{E}$, [8664.4] (Fig. 2). The associated bryophytes were the following: Hypnum cupressiforme, Brachythecium velutinum, Plagiochila porelloides, Atrichum undulatum, Bryum capillare, Metzgeria furcata, and Dicranella heteromalla. Vascular plants in the habitat include Fagus sylvatica, Pinus sylvestris, Quercus cerris, Rubus caesius, Ligustrum vulgare, Campanula persicifolia, C. rotundifolia, Luzula luzuloides, Carex digitata, Hieracium lachenalii, Galium sylvaticum, Viola odorata, and Dryopteris filix-mas.

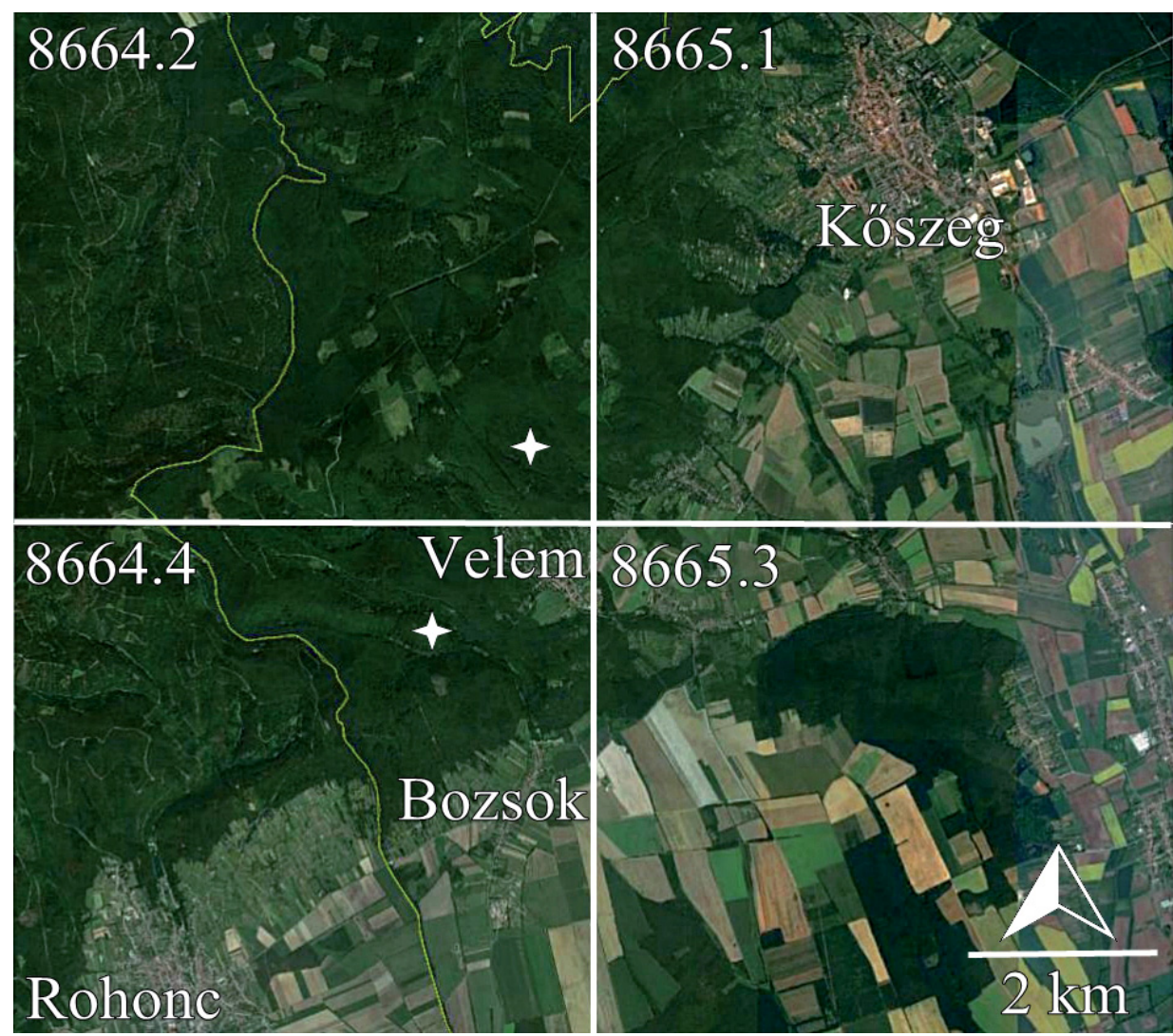

Fig. 2. Geographical location of the two new populations of Heterocladium dimorphum in the Kőszeg Mts. 
On 4th July 2016 an additional population was found ca $1 \mathrm{~km} \mathrm{~N}$ of Velem, near the spring "Borha", at $543 \mathrm{~m}, 47.357777^{\circ} \mathrm{N}, 16.491000^{\circ} \mathrm{E}$, [8664.2] (B-Erzberger 21754, herbarium K. Baráth).

Four colonies of Heterocladium dimorphum covering in total ca $1300 \mathrm{~cm}^{2}$ were present in this site. The soil and the vegetation were quite similar to each other in these two locations (Fig. 3). In this habitat the associated moss species were Hypnum cupressiforme, Atrichum undulatum, Dicranella heteromalla, Brachythecium velutinum, and Pogonatum aloides, while the vascular plants were Fagus sylvatica, Quercus cerris, Pinus sylvestris, Rubus caesius, Hieracium lachenalii, and Luzula luzuloides.

On 1st October 2016 Papp, Erzberger, and Kovács searched the location of one of the oldest collections of Heterocladium dimorphum in BP, the forest margin at the northeastern slope of the hill called "Ábrahámbükk" above Tahi, and succeeded in finding a vigorous population of the species at ca $370 \mathrm{~m}, 47.750000^{\circ}$ $\mathrm{N}, 19.041583^{\circ} \mathrm{E}$ [8280.1] (B-Erzberger 22145). In an area of approximately $50 \mathrm{~m}$ $\times 3 \mathrm{~m}$ numerous colonies were found, covering in total $c$ a $3520 \mathrm{~cm}^{2}$. Associated bryophytes were Atrichum undulatum, Hypnum cupressiforme, Pogonatum aloides, P. nanum, Lophocolea minor, Lophozia bicrenata, and Barbilophozia barbata.

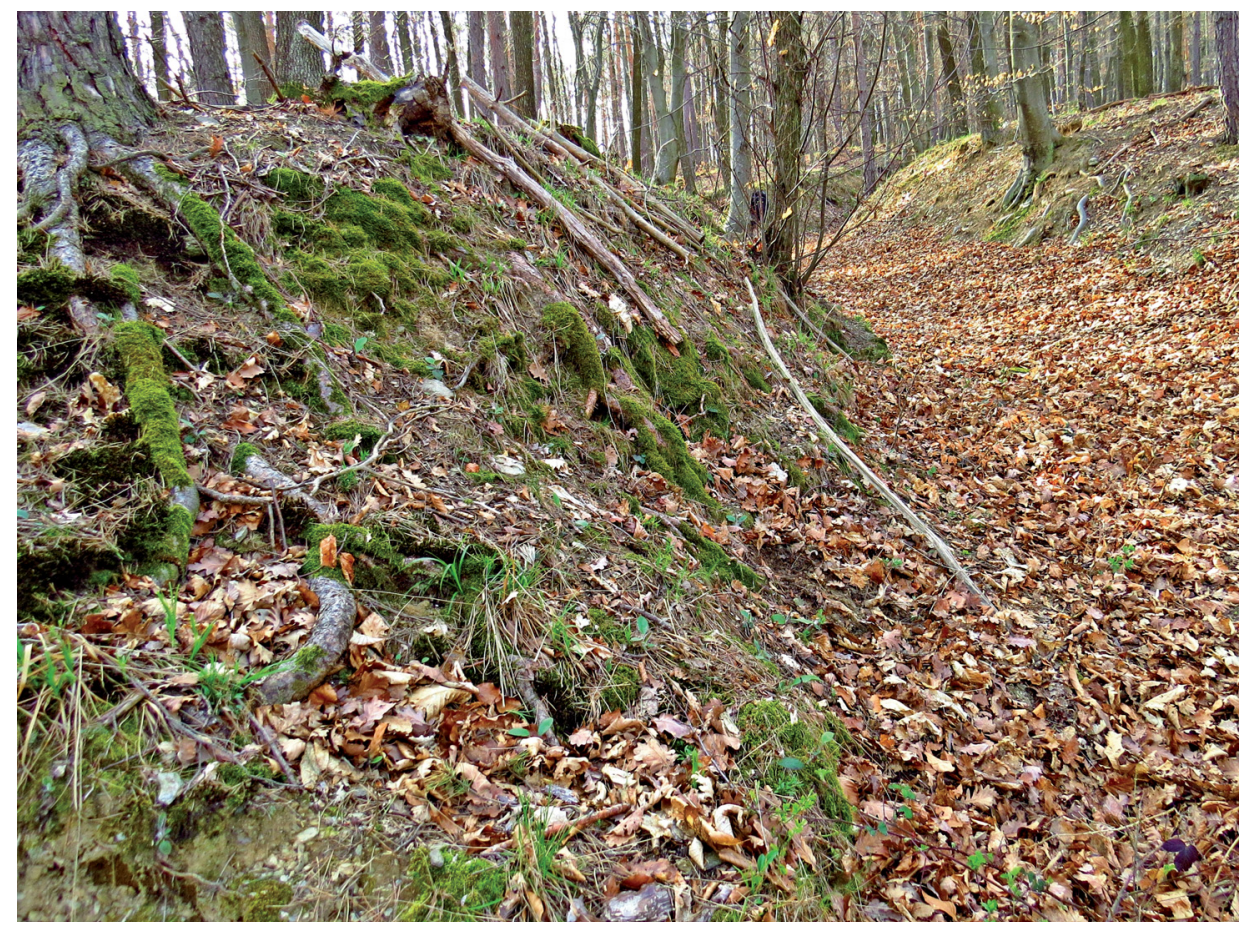

Fig. 3. Habitat of Heterocladium dimorphum in the Köszeg Mts (photo by K. Baráth). 
The previous occurrences of Heterocladium dimorphum in Hungary are listed based on the specimens of the bryophyte collection of the Hungarian Natural History Museum, Budapest (BP) in Table 1. Whereas in some of these specimens sporophytes were noted, we did not detect sporophytes in the recently found populations.

\section{Short characterisation of Heterocladium dimorphum}

Syn.: Heterocladium squarrulosum Lindb., Heterocladium squarrosulum Voit, nom. inval., Hypnum dimorphum Brid.

Plants slender, forming dull or yellowish green patches. Stems procumbent, sometimes stoloniform, pinnately branched. Stem leaves 0.9-1 mm long, squarrose or squarrose-reflexed, broadly ovate, abruptly narrowed to usually long acuminate to filiform acumen, base excavate, decurrent. Margins of the leaves denticulate, serrate or serrulate. Costa short, double. Laminal cells unipapillose, median narrowly rectangular, 5-8 $\times 20-32 \mu \mathrm{m}, 3-5$ times as long as wide, towards margins \pm abruptly rectangular, trapezoid or quadrate-hexagonal. Branch leaves smaller than stem leaves, erecto-patent, concave, ovate, obtuse to acute. Costa short, double. Seta reddish, slightly curved. Capsules elongated ovoid. Capsule lids obtuse.

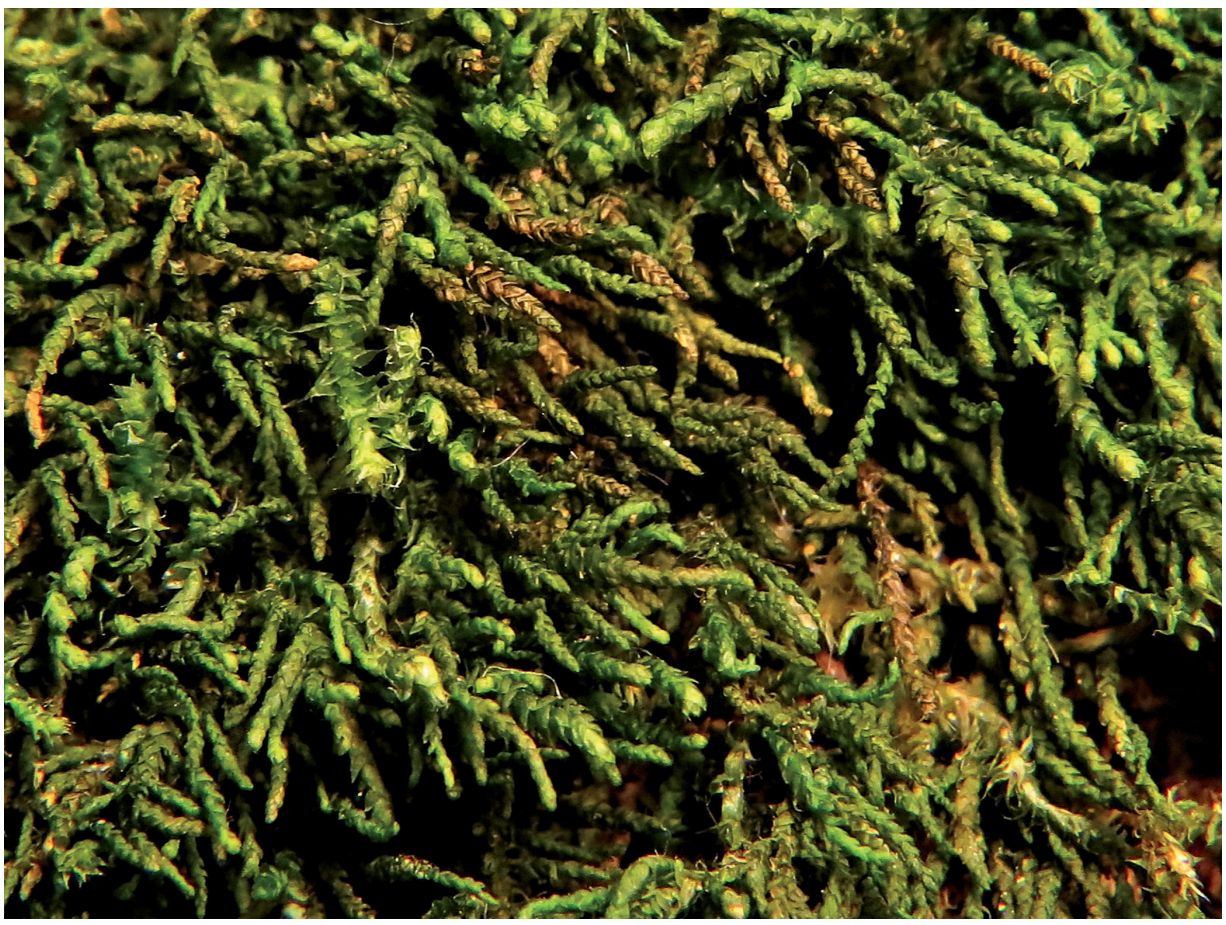

Fig. 4. Habit of Heterocladium dimorphum (photo by K. Baráth). 
Although capsules are rare, its gametophyte is rather characteristic, therefore the species can be safely determined in the field with a 10× hand lens (Figs 4-5). $H$. dimorphum usually grows in shady, woody habitats on loamy or gritty soil and at tree bases. It is a boreal-montane moss species.

Based on the fact that now three extant populations of $H$. dimorphum are known in Hungary, the species can no longer be considered data-deficient, and as an amended red list status we propose endangered (EN), in accordance with the IUCN criteria (IUCN 2014) and recent treatment of similar cases (ERZBERGER et al. 2015).

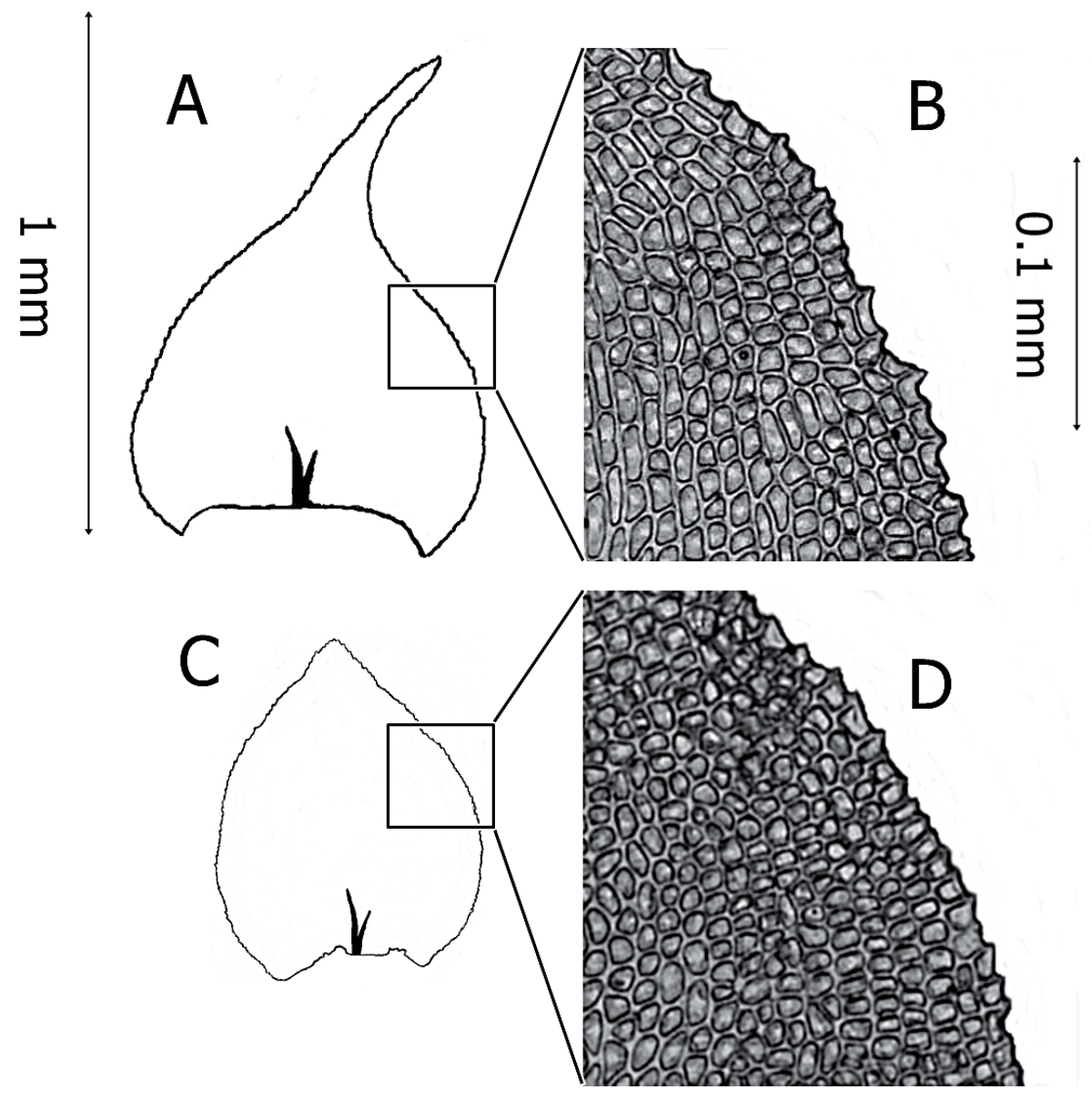

Fig. 5. Leaves and laminal cells of Heterocladium dimorphum. $\mathrm{A}=$ stem leaf; $\mathrm{B}=$ marginal and median laminal cells of stem leaf (margin to the right); $\mathrm{C}=$ branch leaf; $\mathrm{D}=$ marginal and median laminal cells of branch leaf (margin to the right). 
Összefoglaló: A Heterocladium dimorphum Európában, Nyugat-Ázsiában és Észak-Amerikában előforduló, boreális-montán elterjedésű mohafaj. A növényt a múlt század elején és közepén Magyarországon is gyűjtötték, de mivel az elmúlt 47 évben nem került elő, az ország legfrissebb vörös listájában aktuális előfordulás nélküli, adathiányos fajként szerepel. 2016-ban az ország kvadrát alapú mohatérképezése és a Kőszegi-hegység mohaflóráját feltáró terepmunkák során a faj újra előkerült a Kőszegi-hegység két új és a Visegrádi-hegység egy régebbről ismert lelőhelyén. A két újonnan felfedezett kőszegi-hegységi populáció mintegy 15 telepet foglalt magában, amelyek mészkerülő fenyőelegyes lomberdőben, agyagos talajon közel $4700 \mathrm{~cm}^{2}$ borítással rendelkeztek, míg a Visegrádi-hegységben talált populáció alacsony növekedésű bükkös szélén, egy útrézsű $50 \mathrm{~m} \times 3 \mathrm{~m}$-es szakaszán található. A faj borítása itt megközelítőleg $3500 \mathrm{~cm}^{2}$ volt.

\section{REFERENCES}

Boros, Á. (1927): Vasvármegye moha-flórájának elömunkálatai. (Vorarbeiten zu einer Moosflora des Komitates Vas.). - In: VÁRADY, I. (ed.): Vasvármegye és Szombathely város kultúregyesülete és a vasvármegyei Múzeum II. évkönyve, pp. 207-224, 256-259.

Boros, Á. (1953): Magyarország mohái. (Bryophyta Hungariae). - Akadémiai Kiadó, Budapest, 360 pp. Boros, Á. (1968): Bryogeographie und Bryoflora Ungarns. - Akadémiai Kiadó, Budapest, 466 pp.

Brotherus, V. F. (1924): Musci (Laubmoose) 1. Hälfte. - In: Engler, A. and Prantl, K. (eds): Die natürlichen Pflanzenfamilien. Duncker \& Humblot, Berlin, 478 pp.

BUCK, W. R. and CRUM, H. (1990): An evaluation of familial limits among the genera traditionally aligned with the Thuidiaceae and Leskeaceae. - Contr. Univ. Michigan Herb. 17: 55-69.

Buck, W. R. and Goffinet, B. (2000): Morphology and classification of mosses. - In: SHaw, A. J. and Goffinet, B. (eds): Bryophyte biology. Cambridge University Press, Cambridge, pp. $71-123$.

Budyakova, A. A., Ignatov, M. S., Yatsentyuk, S. P. and Troitsky, A. V. (2003): Systematic position of Habrodon (Habrodontaceae, Musci) as inferred from nuclear ITS1 and ITS2 and chloroplast trnL intron and trnL-trnF spacer sequence data. - Arctoa 12: 137-150.

Casas, C., Brugués, M., Cros, R. M. and Sérgio, C. (2006): Handbook of mosses of the Iberian Peninsula and the Balearic Islands. - Institut d'Estudis Catalans, Barcelona, 349 pp.

ERzBerger, P. (2012): Project plan: bryophyte mapping of Hungary. - Program and Abstracts, 8th Conference of European Committee for Conservation of Bryophytes, Budapest, 18-21 April 2012, p. 12.

Erzberger, P. and Németh, Cs. (2013): Mohatérképezés Magyarországon - eredmények az iniciális fázisból. [Bryophyte mapping in Hungary - results from the initial phase]. - II. Aktuális eredmények a kriptogám növények kutatásában konferencia, abstracts, Eger, p. 13.

Erzberger, P., Németh, Cs., Papp, B., Mesterházy, A., Csiky, J. and Baráth, K. (2015): Revision of the red list status of Hungarian bryophytes 1 . New occurrences of species previously thought to be regionally extinct or without recent data. - Studia bot. hung. 46(2): 15-53. https://doi.org/10.17110/studbot.2015.46.2.15

Fleischer, M. (1922): Die Musci der Flora von Buitenzorg. - Brill, Leiden, 379 pp. https://doi.org/10.2307/3242501 
Frey, W. and Stech, M. (2009): Marchantiophyta, Bryophyta, Anthocerotophyta. - In: Frey, W. (ed.): Syllabus of plant families. A. Engler's Syllabus der Pflanzenfamilien 3, Bryophytes and seedless vascular plants. Schweizerbart, Stuttgart, pp. 9-263.

Goffinet, B. and BUCK, R. (2004): Systematics of Bryophyta (mosses): from molecules to a revised classification. In: Goffinet, B., Hollowell, V. and Magill, R. (eds): Molecular systematics of Bryophytes. - Monogr. Syst. Bot. Missouri Bot. Garden 98: 150-167.

HedenÄs, L. (1995): Higher taxonomic level relationships among diplolepidous pleurocarpous mosses - a cladistic overview. - J. Bryol. 18: 723-781. https://doi.org/10.1179/jbr.1995.18.4.723

Hill, M. O., Bell, N., Bruggemann-Nannenga, M. A., Brugues, M., Cano, M. J., Enroth, J., Flatberg, K. I., Frahm, J.-P., Gallego, M. T., Garilleti, R., Guerra, J., Hedenäs, L., Holyoak, D. T., Hyvönen, J., Ignatov, M. S., Lara, F., Mazimpaka, V., Muñoz, J. and SöDERSTRÖM, L. (2006): An annotated checklist of the mosses of Europe and Macaronesia. - J. Bryol. 28: 198-267. http://dx.doi.org/10.1179/174328206X119998

Hodgetts, N. G. (2015): Checklist and country status of European bryophytes - towards a new red list for Europe. - Irish Wildlife Manuals 84: 1-112.

Ignatov, M. S. and Ignatova, E. A. (2004): Flora mkhov srednei chasti evropeiskoi Rossii. Tom 2. Fontinalaceae - Amblystegiaceae. [Moss flora of the Middle European Russia. Volume 2: Fontinalaceae - Amblystegiaceae]. - Arctoa 11(Suppl. 2): 609-960.

Ignatov, M. S., Afonina, O. M. and Ignatova, E. A. (2006): Check-list of Mosses of East Europe and North Asia. - Arctoa 15: 1-130.

IUCN (2014): Guidelines for using the IUCN red list categories and criteria. Version 11. Prepared by the standards and petitions subcommittee. - http://www.iucnredlist.org/documents/ RedListGuidelines.pdf (accessed: 23.11.2015).

KIRÁLY, G. (ed) (2009): Új magyar füvészkönyv Magyarország hajtásos növényei. Határozókulcsok [New Hungarian Herbal. The vascular plants of Hungary. Identification key]. - Aggteleki Nemzeti Park Igazgatóság, Jósvafö, 616 pp.

Latzel, A. (1930): Moose aus dem Komitate Vas u. einigen anderen Komitaten. - Magyar Bot. Lapok 29: 105-138.

Magill, E. R. (2014): Heterocladium. - In: Flora of North America Editorial Committee (ed.): Flora of North America North of Mexico 28, New York and Oxford, pp. 368-370.

Newton, A. E. and TAngney, R. S. (2007): Pleurocarpous mosses: systematics and evolution. - CRC Press, Boca Raton, 464 pp.

Niklfeld, H. (1971): Bericht über die Kartierung der Flora Mitteleuropas. - Taxon 20: 545-571. https://doi.org/10.2307/1218258

Orbán, S. and VAJDA, L. (1983): Magyarország mohaflórájának kézikönyve. - Akadémiai Kiadó, Budapest, $518 \mathrm{pp}$.

Papp, B., Erzberger, P., Ódor, P., Hock, Zs., Szövényi, P., Szurdoki, E. and Tóth, Z. (2010): Updated checklist and red list of Hungarian bryophytes. - Studia bot. hung. 41: 31-59.

Schimper, W. P. (1852): Heterocladium. - In: Schimper, W. P. (ed.): Bryologia Europaea seu genera muscorum Europaeorum. E. Schweizerbart, Stuttgart, pp. 151-155.

Sim-Sim, M., Fontinha, S., Luís, L., Martins, S., Lobo, C., Stech, M. and Frey, W. (2010): The Selvagens Islands bryoflora and its relation with other islands of the Madeira and Canary Islands Archipelagos. - Nova Hedwigia 138: 185-197.

Smith, A. J. E. (2004): The moss flora of Britain and Ireland. Ed. 2. - Cambridge University Press, Cambridge, 1012 pp.

(submitted: 05.10.2016, accepted: 20.11.2016) 